\title{
Microbiological air quality in pharmacies and an antibiotic resistance profile of staphylococci species
}

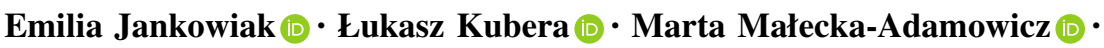 \\ Ewa Dembowska (1)
}

Received: 7 August 2019/Accepted: 29 June 2020/Published online: 10 July 2020

(C) The Author(s) 2020

\begin{abstract}
The air in public facilities contains microorganisms which may cause a wide variety of clinical syndromes in humans. This is particularly important in primary healthcare units, where patients with reduced immunity and staff are directly exposed to microbial pathogens. Air samples were collected from dispensing areas (customer areas) of five pharmacies using MAS-100 air sampler. The concentration of particular groups of microorganisms was determined with the use of selective media. The taxonomic analysis of mannitol-positive bacteria was conducted using the $\mathrm{BIOLOG}^{\circledR}$ method, based on metabolic characteristics of analyzed strains. The isolated molds were identified based on their macroscopic and microscopic features according to available keys. The antimicrobial susceptibility of identified staphylococci was tested using the disk diffusion method in accordance with The European Committee on Antimicrobial Susceptibility Testing recommendations. The highest average concentrations of heterotrophic bacteria and staphylococci were recorded in two hospital pharmacies. The highest average concentrations of molds were recorded in the pharmacies located in
\end{abstract}

E. Jankowiak $(\bowtie) \cdot$ Ł. Kubera .

M. Małecka-Adamowicz · E. Dembowska

Department of Microbiology and Immunobiology, Faculty of Biological Sciences, Kazimierz Wielki University, Al. Powstańców Wielkopolskich 10, 85-090 Bydgoszcz,

Poland

e-mail: emilia.jankowiak@ukw.edu.pl shopping centers. Taxonomic analysis indicated that Cladosporium and Penicillium spp. predominated among the isolated molds while Staphylococcus haemolyticus and Staphylococcus aureus, among mannitol-positive bacteria. Antibiograms showed that the majority of Staphylococcus strains (68.2\%) were resistant to erythromycin. There was a statistically significant correlation between the concentration of investigated bacteria and the season of the year as well as the size and location of the pharmacies. The results demonstrate that there is a range of factors affecting air quality in public spaces and emphasize the fact that pharmacies can be a source of potentially pathogenic, drug-resistant bacteria.

Keywords Airborne bacteria $\cdot$ Staphylococci $\cdot$ Mold fungi $\cdot$ Antimicrobial resistance $\cdot$ Public health

\section{Introduction}

Air, a mixture of gases, is not a natural habitat for microorganisms, because it fails to provide them with necessary nutrients; their presence in the air is frequently associated with humans. Constantly exposed to microorganisms in the environment, people contribute to their transmission. Moreover, owing to air circulation, bacteria, fungi, and fragments of their cells can travel over long distances, which may 
increase the risk of spreading infectious diseases and allergies (Braggoszewska et al. 2018a). Therefore, the monitoring of air microbial quality in public spaces is necessary.

In pharmacies, hospitals and other types of healthcare units staff members and other non-patients with different immunity are unguarded against biological contaminants from infected people. (Veysi et al. 2019). In addition, inadequate cleaning and disinfection procedures have been identified as the main contributors to the spread of infections (Shiferaw et al. 2016).

Bacterial bioaresols contain abundant gram-positive cocci. Recent reports have warned that antibiotic resistance in staphylococci and other bacteria is increasing at an alarming rate. This disturbing phenomenon is caused mainly by the overuse and misuse of antibiotics (Alhomoud et al. 2018, Lenart-Boron et al. 2017). The acquisition of drug resistance also results from bacteria's ability to adapt to different environmental conditions by creating biofilms that facilitate the transfer of resistance genes (Bragoszewska and Biedron 2018). To cope with antibioticinduced stress, bacteria change their gene expression patterns and activate latent defense mechanisms (Palmer et al. 2018). Increased resistance to available drugs poses a serious threat to human health and is a major challenge to modern medicine (Labi et al. 2018).

Moreover, molds, identified as powerful air pollutants, produce spores which can colonize furniture, equipment, ventilation and air-conditioning systems and can survive harsh environmental conditions (Kobza et al. 2018). Allergens from these fungi cause mainly respiratory and skin symptoms (Twaroch et al. 2015), particularly in immunocompromised persons. Good air quality is therefore of paramount importance in preventing hospital-acquired infections (Cho et al. 2018).

There is abundant literature on air quality in various public facilities. However, pharmacies have not been sufficiently investigated. So far the research on bioaerosol concentration and quality in these facilities has been very limited and the available data seem insufficient. For that reason, it seems justified to examine the issue more thoroughly, contributing to better understanding of microorganisms in this environment. Aware of the fact that pharmacies may be a source of potentially pathogenic microorganisms, the authors attempted to provide a comprehensive analysis of microbial population in these places.

The analyses were aimed at the following: (1) determining bioaerosol concentration in dispensing areas in pharmacies, (2) determining the impact of selected factors on the concentration of specific groups of airborne microorganisms, (3) examining the taxonomic diversity of molds and staphylococci, (4) preparing the drug resistance profile of the identified Staphylococcus strains. The results may help to develop relevant standards and control methods regarding acceptable bioaerosol concentrations in pharmacies and other primary health care institutions.

\section{Materials and methods}

\subsection{Sampling sites}

Air samples were collected from dispensing areas of five pharmacies located in the city of Bydgoszcz, Poland. Sampling was conducted in a seasonal cycle: in spring (23 April 2018), summer (10 July 2017), autumn (30 October 2017) and winter (22 January 2018), in three parallel repetitions, using the MAS-100 air sampler (Merck, Germany). Replicates were used to determine the arithmetic mean, which was used in statistical analysis. The collected material was immediately transported in isothermal containers to the laboratory and placed in thermostats. The characteristics of all sampling sites are presented in Table 1.

\subsection{Microbiological analysis}

Nutrient agar (BioMaxima, Poland) was used for quantitative analysis of heterotrophic bacteria. The total concentration of mannitol-positive staphylococci was determined using Mannitol Salt Agar (BioMaxima, Poland). Bacterial cultures were incubated at $37{ }^{\circ} \mathrm{C}$ for 48 h. Mannitol-positive bacteria were Gram stained and identified by their morphological features under the microscope as gram-positive cocci. Quantitative analysis of molds was carried out using Czapek-Dox Agar (BTL, Poland). Plates with the collected material were incubated at $26{ }^{\circ} \mathrm{C}$ for 5 days. The results were corrected using the table of statistical corrections according to Feller (1950) and expressed as colony forming units per cubic meter of air $\left(\mathrm{CFU} \mathrm{m} \mathrm{m}^{-3}\right)$. 
Table 1 Characteristic of sampling sites

\begin{tabular}{lllll}
\hline Sampling sites & Type of pharmacy & Cubic capacity $\left(\mathrm{m}^{3}\right)$ & Type of ventilation & Temperature $\left({ }^{\circ} \mathrm{C}\right)$ \\
\hline I & Pharmacy in a residential area & 161.9 & Mechanical & 21.5 \\
II & Pharmacy in the shopping center & 174.98 & Mechanical & 23.5 \\
III & & 245.63 & Mechanical & 21 \\
IV & Hospital pharmacy & 98.74 & Natural & 21.5 \\
V & & Mechanical & 21 \\
\hline
\end{tabular}

\subsection{Taxonomic analysis}

The BIOLOG $^{\circledR}$ semi-automatic system was used for the identification of gram-positive cocci. Bacteria were streaked over the surface of BUG agar medium (Biolog Universal Growth agar, BIOLOG ${ }^{\circledR}$, USA) and $^{\circ}$ incubated at $37{ }^{\circ} \mathrm{C}$ for $18-24 \mathrm{~h}$. Subsequently, a single colony was transferred to IF-A liquid inoculum of 95-98\% turbidity. The volumes of $0.1 \mathrm{ml}$ of the bacterial suspension were transferred to the wells of GEN III MicroPlateTM and incubated at $37^{\circ} \mathrm{C}$ for $24 \mathrm{~h}$. Reading was performed using Gen III MicroStation ID System/MicroLog $3^{\mathrm{TM}}$ software.

The isolated molds were inoculated and identified based on their macroscopic and microscopic features, using $40 \times$ magnification microscope and appropriate keys (Fassatiová 1983; Samson et al. 2004).

\subsection{Evaluation of antibiotic resistance}

Antibiotic resistance of identified staphylococci was evaluated using the disk diffusion method. Bacterial strains were suspended in sterile physiological saline solution $(0.85 \%)$. This bacterial inoculum was diluted to an optical density equivalent to 0.5 McFarland standard. The volumes of $0.1 \mathrm{ml}$ were placed on Petri plates with Mueller-Hinton II Agar (BioMaxima, Poland). Subsequently, paper disks impregnated with selected antibiotics (Table 2) were placed on the inoculated medium and incubated for $18 \mathrm{~h}$ at $37{ }^{\circ} \mathrm{C}$. After this time, zones of inhibited growth were measured and the results were interpreted in accordance with the guidelines of The European Committee on Antimicrobial Susceptibility Testing (EUCAST 2018).

\subsection{Statistical analysis}

Statistica 13.1 software was used for statistical analysis of the results. After log transformation, the distributions of the results in the analyzed groups were normally distributed, determined by using the Shapiro-Wilk test. The ANOVA test of the main effects was then performed to analyze the influence of independent factors on the data group (dependent variable). Tukey's test was also performed for multiple comparisons of inter-group differences. In order to analyze the relationship between the studied parameters, Spearman correlation coefficient was determined. Statistical tests were carried out at the significance level $p \leq 0.05$.

\section{Results}

The air temperature in the majority of the investigated pharmacies was constant and ranged from 21 to $21.5^{\circ} \mathrm{C}$. The only exception was the pharmacy located in the shopping center (sampling site II), where the temperature was $23.5^{\circ} \mathrm{C}$. The hospital pharmacy (sampling site IV) had natural ventilation while the remaining facilities had mechanical ventilation.

The highest average concentration of heterotrophic bacteria (1277.5 CFU $\mathrm{m}^{-3}$ ) was recorded in one of the hospital pharmacies, i.e., at sampling site $\mathrm{V}$, while the lowest $\left(452.5 \mathrm{CFU} \mathrm{m}^{-3}\right)$, in the pharmacy located in the shopping center, i.e., at sampling site III. Molds were the most abundant $\left(648.8 \mathrm{CFU} \mathrm{m}^{-3}\right)$ in the pharmacy in the shopping center, sampling site II, and the least abundant (186.3 $\mathrm{CFU} \mathrm{m}^{-3}$ ), in the pharmacy in the residential area, sampling site I. Table 3 shows that the highest average concentrations of staphylococci were recorded in the hospital pharmacies (sampling site $\mathrm{IV}-17.9 \mathrm{CFU} \mathrm{\textrm {m } ^ { - 3 }}$, sampling site 
Table 2 List of antibiotics used in the study (Oxoid, UK)

\begin{tabular}{lllr}
\hline Group of Antibiotics & Antibiotics & Disk symbol & Disk content $(\mu \mathrm{g})$ \\
\hline Penicillins & Benzylpenicillin & P1 & 1 \\
Cephalosporins & Cefoxitin & FOX30 & 30 \\
Fluoroquinolones & Levofloxacin & LEV5 & 5 \\
Aminocoumarin & Gentamicin & CN10 & 10 \\
Macrolides & Erythromycin & E15 & 15 \\
Tetracyclines & Tetracycline & TE30 & 30 \\
Drugs against mycobacteria & Chloramphenicol & C30 & 30 \\
& Rifampicin & RD5 & 5 \\
\hline
\end{tabular}

Table 3 The concentration of microorganisms in $1 \mathrm{~m}^{3}$ of air at all sampling sites $(N=4)$

\begin{tabular}{|c|c|c|c|c|}
\hline Type of pharmacy & Sampling site & $\begin{array}{l}\text { Heterotrophic bacteria } \\
\mathrm{M} \pm \mathrm{SD} \text {, range }\left(\mathrm{CFU} \mathrm{m} \mathrm{m}^{-3}\right)\end{array}$ & Mold fungi & Staphylococci \\
\hline Pharmacy in a residential area & I & $\begin{array}{l}672.5 \pm 283.8 \\
(265-920)\end{array}$ & $\begin{array}{l}186.3 \pm 109.5 \\
(120-350)\end{array}$ & $\begin{array}{l}7.0 \pm 2.1 \\
(5-10)\end{array}$ \\
\hline \multirow[t]{2}{*}{ Pharmacy in the shopping center } & II & $\begin{array}{l}742.5 \pm 381.6 \\
(255-1080)\end{array}$ & $\begin{array}{l}648.8 \pm 514.6 \\
(90-1320)\end{array}$ & $\begin{array}{l}11.1 \pm 7.0 \\
(3-20)\end{array}$ \\
\hline & III & $\begin{array}{l}452.5 \pm 160.1 \\
(265-640)\end{array}$ & $\begin{array}{l}248.8 \pm 117.6 \\
(115-380)\end{array}$ & $\begin{array}{l}7.3 \pm 5.5 \\
(1.5-13.5)\end{array}$ \\
\hline \multirow[t]{2}{*}{ Hospital pharmacy } & IV & $\begin{array}{l}793.8 \pm 99.6 \\
(680-900)\end{array}$ & $\begin{array}{l}268.4 \pm 104.1 \\
(130-356.5)\end{array}$ & $\begin{array}{l}17.9 \pm 4.4 \\
(13.5-23)\end{array}$ \\
\hline & $\mathrm{V}$ & $\begin{array}{l}1277.5 \pm 610.3 \\
(620-2070)\end{array}$ & $\begin{array}{l}235.4 \pm 73.2 \\
(165-306.5)\end{array}$ & $\begin{array}{l}15.1 \pm 3.6 \\
(12-20)\end{array}$ \\
\hline
\end{tabular}

$M$ mean, $S D$ standard deviation

$\mathrm{V}-15.1 \mathrm{CFU} \mathrm{m}^{-3}$ ), while the lowest, in the pharmacy in a residential area (sampling site I$7 \mathrm{CFU} \mathrm{m}{ }^{-3}$ ) and the pharmacy in the shopping center (sampling site III-7.3 $\mathrm{CFU} \mathrm{m}{ }^{-3}$ ). The results of microbiological air analysis are presented in Tables 3 and 4.
The concentration of heterotrophic bacteria depended on the season of the year: in winter their concentration decreased to $509 \mathrm{CFU} \mathrm{m}^{-3}$, in spring, increased sharply to $950 \mathrm{CFU} \mathrm{m}^{-3}$, to reach the maximum in summer $\left(1054 \mathrm{CFU} \mathrm{m}^{-3}\right)$. In autumn it decreased again to $638 \mathrm{CFU} \mathrm{m}^{-3}$. On the contrary, the
Table 4 The concentration of microorganisms in $1 \mathrm{~m}^{3}$ of air in pharmacies depending on the season $(N=5)$

$M$ mean, $S D$ standard deviation

\begin{tabular}{llll}
\hline Research season & $\begin{array}{l}\text { Heterotrophic bacteria } \\
\mathrm{M} \pm \mathrm{SD}, \text { range }\left(\mathrm{CFU} \mathrm{m}{ }^{-3}\right)\end{array}$ & Mold fungi & Staphylococci \\
\hline \multirow{2}{*}{ Spring } & $950 \pm 286.4$ & $250 \pm 255.0$ & $14.4 \pm 5.7$ \\
& $(745-1365)$ & $(115-705)$ & $(6.5-20)$ \\
Summer & $1054 \pm 597.7$ & $222 \pm 130.8$ & $11.6 \pm 6.3$ \\
& $(780-2070)$ & $(90-380)$ & $(3-20)$ \\
Autumn & $638 \pm 322.9$ & $314.6 \pm 122.7$ & $11.8 \pm 7.8$ \\
& $(265-1055)$ & $(140-480)$ & $(4-23)$ \\
Winter & $509 \pm 230.4$ & $483.4 \pm 471.4$ & $8.9 \pm 5.0$ \\
& $(255-725)$ & $(247-1320)$ & $(1.5-13.5)$ \\
\hline
\end{tabular}


highest average concentrations of molds were recorded in autumn $\left(314.6 \mathrm{CFU} \mathrm{m}^{-3}\right)$ and winter (483.4 $\mathrm{CFU} \mathrm{m}^{-3}$ ), while the lowest, in summer $\left(222 \mathrm{CFU} \mathrm{m}^{-3}\right)$ and spring $\left(250 \mathrm{CFU} \mathrm{m}{ }^{-3}\right)$. The highest concentration of staphylococci was recorded in spring $\left(14.4 \mathrm{CFU} \mathrm{m}^{-3}\right)$, and the lowest, in winter (8.9 $\mathrm{CFU} \mathrm{m}^{-3}$ ).

The total concentration of heterotrophic bacteria was correlated with the size of the pharmacies (Fig. 1a). Pharmacies of smaller cubic capacity were characterized by a higher total bacterial concentration $(r=-0.9, p<0.05)$. A similar relationship was observed for staphylococci (Fig. 1c): there was a negative correlation between their concentration and the size of the investigated facilities $(r=-0.6$, $p>0.05$ ). However, this result was not statistically significant. In contrast, the concentration of molds was not correlated with the size of the pharmacies (Fig. 1b).

Analysis of variance showed that the concentration of the studied bacterial groups depended on the sampling site and the season of the year. Significant differences in the concentration of heterotrophic bacteria were found between sites III and V and between summer and winter. The concentration of staphylococci was determined only by the location of the sampling sites; significant differences were noted between sites I and IV. In all these cases the significance level was $p<0.05$. However, no significant spatiotemporal differences in the concentration of molds were observed.

As many as 675 species of molds belonging to 11 genera were isolated from the collected air samples (Fig. 2). The results indicated that Cladosporium
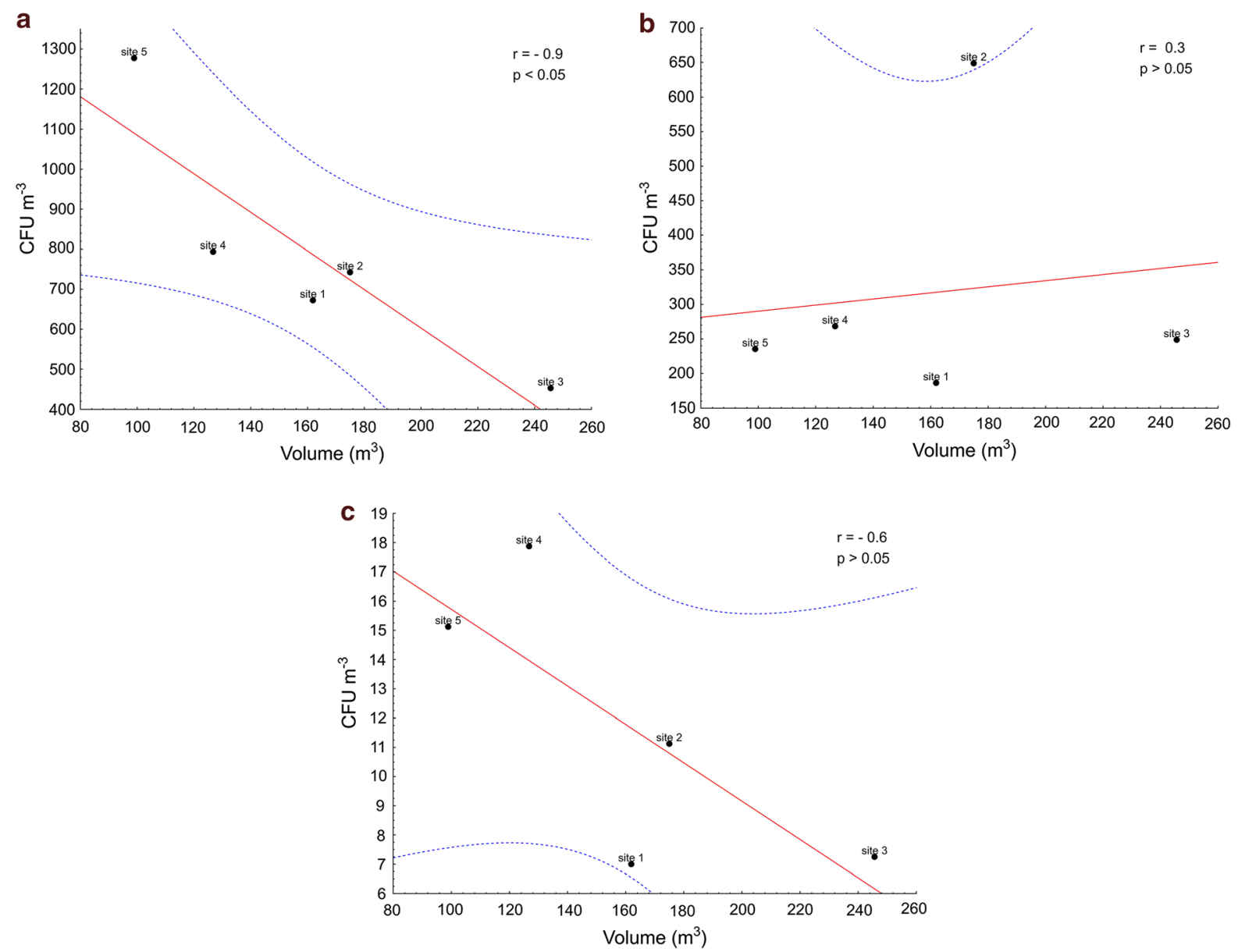

Fig. 1 The relationship between a the size of the pharmacies and the total number of heterotrophic bacteria, b the size of the pharmacies and the total number of molds, $\mathbf{c}$ the relationship between the size of the pharmacies and the total number of staphylococci 
a

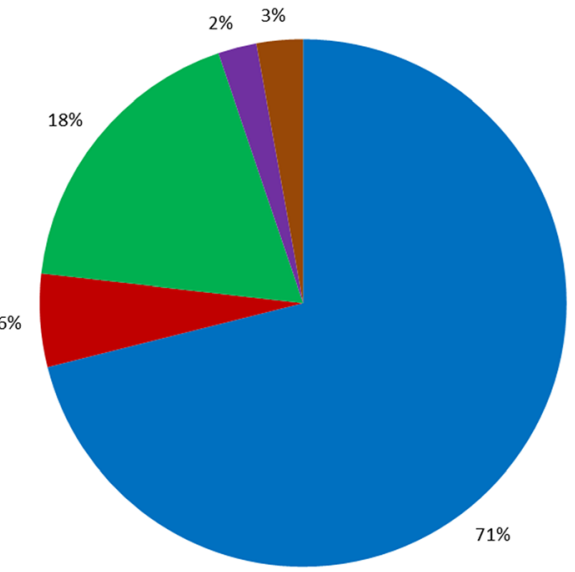

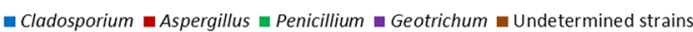

\section{c}

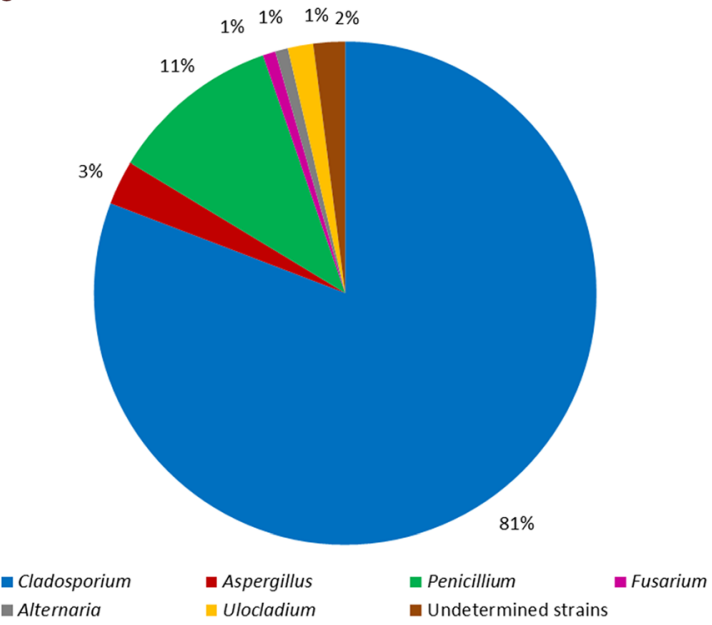

b

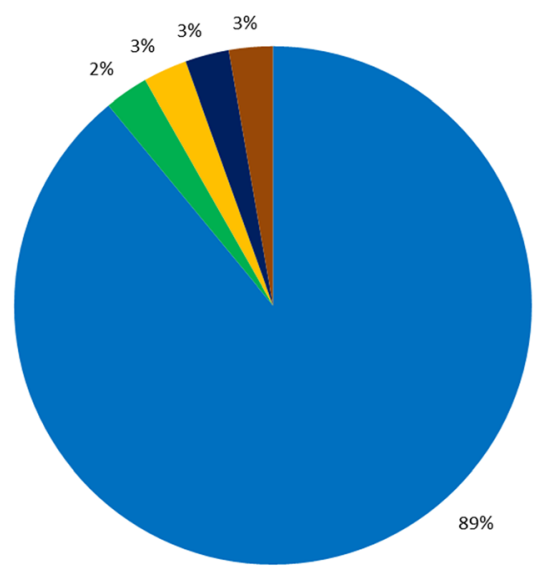

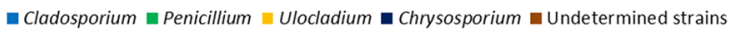

d

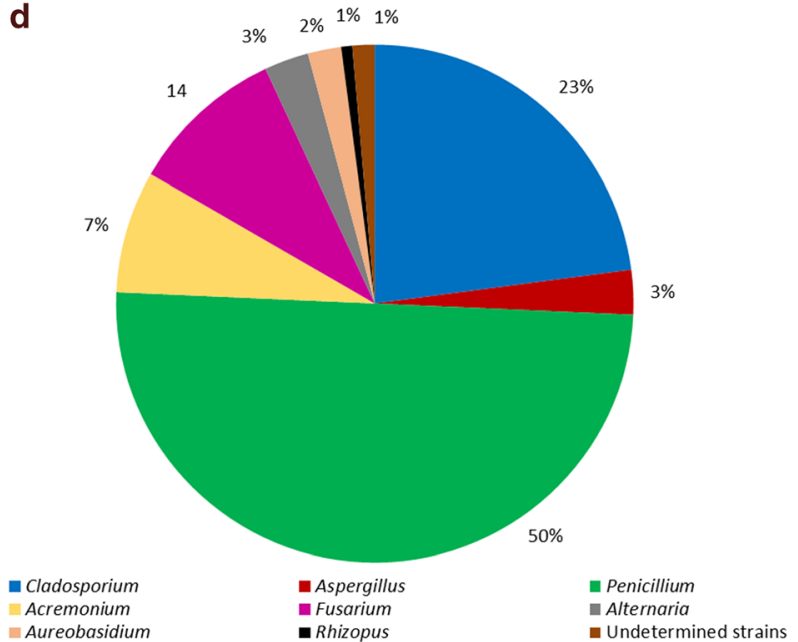

Fig. 2 Percentage share of the isolated molds in all research seasons a spring $(N=212)$, b summer $(N=74)$, c autumn $(N=245)$, d winter $(N=144)$

genus were the most abundant in the air of the examined pharmacies in spring (71\%), summer (89\%), and autumn (81\%) (Fig. 2a-c). In winter, the fungal community was dominated by Penicillium genus $(50 \%)$. Moreover, in winter the taxonomic diversity of airborne molds was the highest, while particular genera had a low percentage share (Fig. 2d). Other genera of molds occurred sporadically.

The collected air samples contained 11 species of mannitol-positive bacteria and 10 species of staphylococci, with the dominance of Staphylococcus haemolyticus (38\%) and Staphylococcus aureus (13\%). The results of the taxonomic analysis of the isolated strains are presented in Table 5.
All isolated Staphylococcus strains $(n=22)$ were susceptible to chloramphenicol (100\%), 68.2\% were resistant to erythromycin, $36.4 \%$ were resistant to cefoxitin, $18.2 \%$, to tetracycline, and $13.6 \%$, to gentamicin. Only $4.5 \%$ of all isolates were resistant to both rifampicin and levofloxacin.

Two of the three studied strains of $S$. aureus (33.3\%) were susceptible to benzylpenicillin, a $\beta$ lactam antibiotic. There were no multidrug-resistant strains. The antibiotic resistance of iolated staphylococci is presented in Table 6 . 
Table 5 Taxonomy of isolated strains $(N=24)$ based on Bergey's Manual of Systematic Bacteriology (Vos et al. 2009)

\begin{tabular}{|c|c|c|c|c|c|}
\hline Phylum & Class & Order & Family & Genus/species & Percentage $(\%)$ \\
\hline \multirow[t]{11}{*}{ Firmicutes } & Bacilli & Bacillales & Staphylococcaceae & Staphylococcus haemolyticus & 38 \\
\hline & & & & Staphylococcus aureus & 13 \\
\hline & & & & Staphylococcus capitis & 9 \\
\hline & & & & Staphylococcus warneri & 8 \\
\hline & & & & Staphylococcus epidermidis & 4 \\
\hline & & & & Staphylococcus hominis & 4 \\
\hline & & & & Staphylococcus lentus & 4 \\
\hline & & & & Staphylococcus saprophyticus & 4 \\
\hline & & & & Staphylococcus sciuri & 4 \\
\hline & & & & Staphylococcus xylosus & 4 \\
\hline & & & & Macrococcus equipercicus & 8 \\
\hline
\end{tabular}

Table 6 Antibiotic resistance of staphylococci, determined by the disk diffusion method

(R) - resistant, (-) susceptible

P1 benzylpenicillin, E15 erythromycin, $R D 5$ rifampicin, $\mathrm{CN} 10$ gentamicin, FOX30 cefoxitin, TE30 tetracycline, C30 chloramphenicol, LEV5 levofloxacin

\begin{tabular}{|c|c|c|c|c|c|c|c|c|c|}
\hline \multirow[t]{2}{*}{ No. } & \multirow[t]{2}{*}{ Species } & \multicolumn{8}{|c|}{ Antibiotic resistance } \\
\hline & & $\mathrm{P} 1$ & E15 & RD5 & CN10 & FOX30 & TE30 & $\mathrm{C} 30$ & LEV5 \\
\hline 1. & S. haemolyticus & & $\mathrm{R}$ & - & - & - & - & - & - \\
\hline 2. & S. haemolyticus & & $\mathrm{R}$ & - & $\mathrm{R}$ & $\mathrm{R}$ & $\mathrm{R}$ & - & - \\
\hline 3. & S. haemolyticus & & $\mathrm{R}$ & - & - & $\mathrm{R}$ & - & - & - \\
\hline 4. & S. haemolyticus & & $\mathrm{R}$ & - & - & $\mathrm{R}$ & - & - & - \\
\hline 5. & S. haemolyticus & & $\mathrm{R}$ & - & - & $\mathrm{R}$ & - & - & - \\
\hline 6. & S. haemolyticus & & $\mathrm{R}$ & - & - & - & - & - & - \\
\hline 7. & S. haemolyticus & & $\mathrm{R}$ & - & $\mathrm{R}$ & $\mathrm{R}$ & - & - & - \\
\hline 8. & S. haemolyticus & & $\mathrm{R}$ & - & - & $\mathrm{R}$ & $\mathrm{R}$ & - & $\mathrm{R}$ \\
\hline 9. & S. haemolyticus & & $\mathrm{R}$ & - & - & $\mathrm{R}$ & $\mathrm{R}$ & - & - \\
\hline 10. & S. aureus & - & $\mathrm{R}$ & - & - & - & - & - & - \\
\hline 11. & S. aureus & $\mathrm{R}$ & - & - & - & - & $\mathrm{R}$ & - & - \\
\hline 12. & S. aureus & - & - & - & - & - & - & - & - \\
\hline 13. & S. capitis & & $\mathrm{R}$ & - & - & - & - & - & - \\
\hline 14. & S. capitis & & $\mathrm{R}$ & - & - & - & - & - & - \\
\hline 15. & $S$ warneri & & - & - & - & - & - & - & - \\
\hline 16. & $S$ warneri & & $\mathrm{R}$ & - & - & - & - & - & - \\
\hline 17. & S. epidermidis & & $\mathrm{R}$ & - & $\mathrm{R}$ & $\mathrm{R}$ & $\mathrm{R}$ & - & - \\
\hline 18. & S. hominis & & - & - & - & - & - & - & - \\
\hline 19. & S. lentus & & - & - & - & - & - & - & - \\
\hline 20. & S. saprophyticus & & $\mathrm{R}$ & - & - & - & - & - & - \\
\hline 21. & S. sciuri & & - & $\mathrm{R}$ & - & - & - & - & - \\
\hline 22. & S. xylosus & & - & - & - & - & - & - & - \\
\hline \multicolumn{2}{|c|}{ Percent of resistance } & $33.3 \%$ & $68.2 \%$ & $4.5 \%$ & $13.6 \%$ & $36.4 \%$ & $18.2 \%$ & $0 \%$ & $4.5 \%$ \\
\hline
\end{tabular}




\section{Discussion}

Microbiological assessment of indoor air quality has become quite common due to the diversity of airborne microorganisms, Air analyses have been conducted in public facilities, workplaces and residential homes, i.e., where people are regularly exposed to microbial contaminants (Augustowska and Dutkiewicz 2006; Brągoszewska and Pastuszka 2018; Brạgoszewska et al. 2018a, b; Kubera et al. 2015; MałeckaAdamowicz et al. 2019; Miletto and Lindow 2015).

\subsection{Bacterial bioaresol concentration}

Our results indicated that heterotrophic bacteria were the most abundant microorganisms in the air of the investigated pharmacies. Similar results were obtained by Bolookat et al. (2018) investigating hospital in Tehran: the average concentration of bacteria (919 CFU $\mathrm{m}^{-2}$ ) was higher than the average concentration of molds (796 CFU m ${ }^{-2}$ ). The highest average concentration of heterotrophic bacteria was recorded in summer (1054 $\left.\mathrm{CFU} \mathrm{m}^{-3}\right)$ and the lowest, in winter (509 CFU m ${ }^{-3}$ ). Brągoszewska and Pastuszka (2018), who also observed lower bacterial concentrations in winter, attributed that to low temperatures. The highest concentrations of heterotrophic bacteria were recorded in the hospital pharmacies. In the investigated pharmacies the average concentration of heterotrophic bacteria ranged from $452.5 \mathrm{CFU} \mathrm{m}^{-3}$ to 1277.5 $\mathrm{CFU} \mathrm{m} \mathrm{m}^{-3}$. The highest concentration was recorded in the hospital pharmacy (sampling site $\mathrm{V}-1277.5 \mathrm{CFU} \mathrm{m}{ }^{-3}$ ), and the lowest, in the pharmacy in the shopping center (sampling site III452.5 $\mathrm{CFU} \mathrm{m}^{-3}$ ). Augustowska and Dutkiewicz (2006) recorded lower concentrations of these bacteria at a pulmonology ward in Lublin.

At present there are no effective methods of monitoring microbial air pollution. What is more, standards for microbial air quality control have been withdrawn. Brągoszewska and Pastuszka (2018) maintain that this is due to a huge variety of airborne bacteria and the use of a many different measuring methods.

\subsection{Concentration and identification of molds}

The highest average concentration of molds was recorded in winter $\left(483.4 \mathrm{CFU} \mathrm{m}^{-3}\right)$, while the lowest, in summer $\left(222 \mathrm{CFU} \mathrm{m}^{-3}\right)$ and spring $\left(250 \mathrm{CFU} \mathrm{m}^{-3}\right)$. Different results were obtained by Cho et al. (2018), who noted the highest concentrations of molds in spring and summer. At the same time Park et al. (2013) recorded higher mold concentrations in hospital halls in autumn than in summer and winter, which partly confirms our observations. The highest concentration of molds was recorded in the pharmacy located in the shopping center (sampling site II), with the average concentration of $648.8 \mathrm{CFU} \mathrm{m}^{-3}$, and the lowest, in the district pharmacy (sampling site I186.3 $\mathrm{CFU} \mathrm{m}^{-3}$ ). The highest contamination with mold fungi at Sampling Site II may be connected with the fact that this facility did not have an air conditioning system for a prolonged period of time when the owners were waiting for the replacement of the damaged air conditioner. Mechanical ventilation systems without appropriate filters or when the filters are dirty (e.g., covered with dust) can also be a source of molds (Mensah-Attipoe and Toyinbo 2019). In addition, poor or damaged ventilation can lead to moisture accumulation and mold growth. D'Amato et al. (2018) emphasize that the increased use of airconditioners affects human health. Plaskowska et al. (2011) state that proper maintenance of air conditioning systems protects against the negative impact of fungal contamination. Poor air quality can lead to lung diseases and allergies and induce non-specific symptoms (sick building syndrome) (Pallabi 2018). Augustowska and Dutkiewicz (2006) obtained much lower mold concentrations in the air (9.9-96.1 $\left.\mathrm{CFU} \mathrm{m}^{-3}\right)$ at a respiratory ward.

In spring, summer, and autumn Cladosporium species were predominant among molds in the air of the dispensing areas of the investigated pharmacies. Similar results were obtained by Kubera et al. 2015 in kindergartens (67.5\%). Karimpour et al. (2019) noted the dominance of Penicillium spp. (45.86\%) and Cladosporium spp. (31.92\%) at the Children's Medical Centre in Tehran. Similar results were obtained by Ökten et al. (2014) examining indoor air quality at the cancer centre in Trakya, where Penicillium spp. were the most abundant, followed by Cladosporium spp. At the same time Dehghani et al. (2018) recorded a significantly lower concentrations of Cladosporium in the operating blocks in hospitals. The difference may result from different amount of outside air entering the rooms. Moreover, in our study the concentration of Cladosporium was lower in winter, while Penicillium 
species were the most abundant. That partially corresponds to the observations of Azimi et al. (2013) that Penicillium species predominated in winter and spring. In addition, studies by Pląskowska et al. (2011, 2012) demonstrated that Cladosporium were more abundant in summer. In the pharmacy that the authors investigated they accounted for over $80 \%$ of all molds. Antón et al. (2019) report that the most abundant sporulation of Cladosporium occurs in summer and early autumn. In other studies Aspergillus spp. were the most common molds isolated from the hospital environment, constituting 49.9\% (Bolookat, et al. 2018) and 47\% (Cho et al. 2018) of all molds.

\subsection{Staphylococcus concentration and identification}

The highest average concentration of staphylococci was recorded in summer $\left(14.4 \mathrm{CFU} \mathrm{m}^{-3}\right)$ and the lowest, in winter $\left(8.9 \mathrm{CFU} \mathrm{m}^{-3}\right)$. The highest concentrations of these microorganisms were recorded in two hospital pharmacies i.e., at sampling site IV (Bydgoszcz Research Hospital and Polyclinic17.9 CFU m-3) and $\mathrm{V}$ (University Hospital15.1 $\mathrm{CFU} \mathrm{m}^{-3}$ ), while the lowest, in the district pharmacy (sampling site I-7.0 CFU $\mathrm{m}^{-3}$ ). Staphylococcus strains are commonly associated with nosocomial infections. Furthermore, Boada et al. (2018) report that approximately $20 \%$ of human population, predominantly children, may carry $S$. aureus. Results obtained by Sapkota et al. (2016) showed that Staphylococcus aureus was the most common bacterial contaminant on objects in many hospital wards in Nepal. Rings, watches and bracelets worn by medical staff may also be the source of microorganisms (Khodavaisy et al. 2011). Research carried out by Lis et al. (2009) confirmed that people connected with the hospital environment (staff, patients and visitors) may contribute to the spread of staphylococci via air. High concentrations of these bacteria were also recorded in kindergartens (Kubera et al. 2015), which indicates the possible presence of potentially harmful microorganisms in other public places. Air contamination with staphylococci in the investigated pharmacies was significantly lower than that recorded by Karwowska et al. (2013) in a health center in Warsaw, where the concentration of staphylococci ranged from 10 to $305 \mathrm{CFU} \mathrm{m}^{-3}$. In the investigated pharmacies the highest concentration of staphylococci was noted in spring (14.4 $\mathrm{CFU} \mathrm{m} \mathrm{m}^{-3}$ ), and the lowest, in winter $\left(8.9 \mathrm{CFU} \mathrm{m}^{-3}\right)$. Our results correspond to those obtained by Kępa et al. (2008) in the operating block in the hospital in Sosnowiec, where the average concentration of these microorganisms was lower in November than in March.

Particular attention should be paid to staphylococci. They are commonly found on the skin and mucous membranes of humans (Tršan et al. 2019). In our study, Staphylococcus haemolyticus strains were the most abundant in the airborne bacterial community. The results differed from those obtained by LenartBoron et al. (2017) in the apartments of Cracow, where $S$. haemolyticus accounted only for a small percentage of all isolated strains. Pinheiro et al. (2015), who examined isolates from blood cultures, states that $S$. haemolyticus is among microorganisms responsible for severe device-associated infections. Although $S$. haemolyticus has a rather low potential to cause serious nosocomial infections, it may contribute to the emergence of antibiotic and antimicrobial resistance due to the high plasticity of the genome (Czekaj et al. 2015).

\subsection{Resistance profile of identified Staphylococcus strains}

Increased antimicrobial resistance of bacteria poses a serious threat to public health (Peterson and Kaur 2018). The lack of new antimicrobial drugs, easy access to antibiotics, and rapid growth of multidrug resistance create the need for an interdisciplinary approach to alternative therapies (preventive and supportive) (Aslam et al. 2018; Horumpende et al. 2018).

The analysis demonstrated that chloramphenicol, rifampicin and levofloxacin were the most effective antibiotics for selected bacterial isolates. Susceptibility to levofloxacin was most likely caused by increased levofloxacin activity against Gram-positive bacteria (May et al. 2014).

A high percentage of the isolated staphylococci exhibited resistance to erythromycin (macrolide antibiotic). This observation coincides with that of Frías-De León et al. (2015) and Lenart-Boroń et al. (2017), whose Staphylococcus isolates were also frequently resistant to erythromycin.

As recommended by the EUCAST, susceptibility to penicillin was tested only in $S$. aureus, due to the low 
reliability of penicillinase detection in coagulasenegative staphylococci. Lowy (2003) emphasized that over $80 \%$ of staphylococci isolated from hospital environments were resistant to penicillin, which resulted from their ability to produce penicillinase. More than $90 \%$ of staphylococci are able to produce this enzyme, which ensures their resistance to most penicillins (EUCAST 2018).

Since many pathogens can be easily transmitted through the air, antibiotics are frequently used to prevent the spread of infections, and this leads to the emergence of multidrug-resistant strains (Nahaei et al. 2015). Many initiatives are being launched in efforts to reduce or slow down the rate of increase in resistance. Since rational use of antibiotics is so important, targeted antibacterial therapies, consistent with the antibiotic susceptibility profiles of bacterial strains, have been suggested very recently, (Mitsakakis et al. 2018). Finally, there are many ways to maintain good air quality including regular microbiological testing (Pallabi 2018).

\subsection{The impact of selected factors}

on the concentration of microorganisms

According to ASHRAE 170 standards, temperature in healthcare facilities should range from 21 to $24{ }^{\circ} \mathrm{C}$ (ASHRAE 2008). All the investigated pharmacies complied with this requirement (temperature range 21-23.5 ${ }^{\circ} \mathrm{C}$ ) Mousavi et al. (2019), examining the impact of several factors on bioaerosol concentration in hospitals, discovered that temperature had no significant effect on microbial concentration. In our study four pharmacies had mechanical ventilation and only one (sampling site IV) had natural ventilation. However, this fact did not cause any significant differences in temperature and microbial growth. Different observations were made by Stockwell et al. (2019), who recorded significantly higher bioaerosol concentrations $\left(201 \mathrm{CFU} \mathrm{m}^{-3}\right.$ ) in areas with natural ventilation as compared to areas with mechanical ventilation $\left(20 \mathrm{CFU} \mathrm{\textrm {m } ^ { - 3 }}\right)$ in hospitals.

The results indicated that the smaller cubic capacity of a facility may contribute to a higher concentration of airborne bacteria. In addition, in popular/busy pharmacies the spread of pathogenic bacteria increases. This is particularly important in primary health care units, where visitors, mainly patients, emit microorganisms while coughing or sneezing (LenartBoroń et al. 2017).

Meteorological and environmental conditions also affect bacterial concentration in the air (Fang et al. 2018). Our results confirmed the observations of Krajewska-Kułak et al. (2010) and Pląskowska et al. (2011) that the following factors contribute to air quality: season of the year, type of premises (open, closed), its function (laboratory, factory, health care facility), its size (cubic capacity), air conditioning, and number of people (working and visiting). Brągoszewska and Pastuszka (2018) report that the concentration of airborne bacteria also depends on the geographical location of the premises and seasonal variations in bacterial composition. In many countries these factors are analyzed and monitored regularly (Gola et al. 2019).

\section{Conclusions}

1. The highest concentration of heterotrophic bacteria and staphylococci was recorded in pharmacies located in hospital buildings. The highest concentration of molds was recorded in pharmacies located in shopping centers.

2. Higher temperature in spring and summer was the likely cause of the increased concentration of heterotrophic bacteria and staphylococci in the air of the investigated facilities.

3. There was a statistically significant relationship between the size of the examined rooms and the concentration of the studied groups of microorganisms. Higher concentration of heterotrophic bacteria and staphylococci was recorded in pharmacies with a smaller cubic capacity.

4. Taxonomic analysis indicated that Cladosporium spp. were the most abundant molds in springsummer-autumn season and Penicillium, in winter. Staphylococcus haemolyticus and Staphylococcus aureus were the most abundant among mannitol-positive bacteria.

5. Staphylococcus strains showed the highest susceptibility to chloramphenicol and highest resistance to erythromycin.

Acknowledgements This study was supported by the Polish Minister of Science and Higher Education, under the program 
"Regional Initiative of Excellence" in 2019-2022 (Grant No. 008/RID/2018/19).

\section{Compliance with ethical standards}

Conflict of interest The authors declare that they have no conflict of interest.

Open Access This article is licensed under a Creative Commons Attribution 4.0 International License, which permits use, sharing, adaptation, distribution and reproduction in any medium or format, as long as you give appropriate credit to the original author(s) and the source, provide a link to the Creative Commons licence, and indicate if changes were made. The images or other third party material in this article are included in the article's Creative Commons licence, unless indicated otherwise in a credit line to the material. If material is not included in the article's Creative Commons licence and your intended use is not permitted by statutory regulation or exceeds the permitted use, you will need to obtain permission directly from the copyright holder. To view a copy of this licence, visit http://creativecommons.org/licenses/by/4.0/.

\section{References}

Alhomoud, F., Almahasnah, R., \& Alhomoud, F. K. (2018). "You could lose when you misuse"-Factors affecting over-the-counter sale of antibiotics in community pharmacies in Saudi Arabia: A qualitative study. BMC Health Services Research, 18, 915. https://doi.org/10.1186/ s12913-018-3753-y.

Antón, S. F., Cruz, D. R., Sánchez, J. S., \& Reyes, E. S. (2019). Analysis of the airborne fungal spores present in the atmosphere of Salamanca (MW Spain): A preliminary survey. Aerobiologia. https://doi.org/10.1007/s10453-01909569-z.

ASHRAE. (2008). Wentylacja zakładów opieki zdrowotnej. ASHRAE Standard: 170.

Aslam, B., Wang, W., Arszad, M. I., et al. (2018). Antibiotic resistance: A rundown of a global crisis. Infection and Drug Resistance, 11, 1645-1658. https://doi.org/10.2147/ IDR.S173867.

Augustowska, M., \& Dutkiewicz, J. (2006). Variability of airborne microflora in a hospital ward within a period of one year. Annals of Agricultural and Environmental Medicine, 13, 99-106.

Azimi, F., Naddafi, K., Nabizadeh, R., et al. (2013). Fungal air quality in hospital rooms: a case study in Tehran, Iran. Journal of Environmental Health Sciences \& Engineering, 11, 30. https://doi.org/10.1186/2052-336X-11-30.

Boada, A., Pons-Vigués, M., \& Real, J. (2018). Previous antibiotic exposure and antibiotic resistance of commensal Staphylococcus aureus in Spanish primary care. European Journal of General Practice, 24(1), 125-130. https://doi. org/10.1080/13814788.2018.1444748.

Bolookat, F., Hassanvand, M. S., Faridi, S., et al. (2018). Assessment of bioaerosol particle characteristics at different hospital wards and operating theaters: A case study in Tehran. MethodsX, 5, 1588-1596. https://doi.org/10. 1016/j.mex.2018.11.021.

Brągoszewska, E., \& Biedron, I. (2018). Indoor air quality and potential health risk impacts of exposure to antibiotic resistant bacteria in an office rooms in Southern Poland. International Journal of Environmental Research and Public Health, 15, 2604. https://doi.org/10.3390/ ijerph15112604.

Brągoszewska, E., Biedroń, I., Kozielska, B., \& Pastuszka, J. S. (2018a). Microbiological indoor air quality in an office building in Gliwice, Poland: Analysis of the case study. Air Quality, Atmosphere and Health, 11, 729-740. https://doi. org/10.1007/s11869-018-0579-z.

Brągoszewska, E., Mainka, A., Pastuszka, J. S., et al. (2018b). Assessment of bacterial aerosol in a preschool, primary school and high school in Poland. Atmosphere, 9(3), 87. https://doi.org/10.3390/atmos9030087.

Brągoszewska, E., \& Pastuszka, J. S. (2018). Influence of meteorological factors on the level and characteristics of culturable bacteria in the air in Gliwice, Upper Silesia (Poland). Aerobiologia (Bologna), 34(2), 241-255. https:// doi.org/10.1007/s10453-018-9510-1.

Cho, S. Y., Myong, J. P., Kim, W. B., et al. (2018). Profiles of environmental mold: Indoor and outdoor air sampling in a hematology hospital in Seoul, South Korea. International Journal of Environmental Research and Public Health, 15(11), 2560. https://doi.org/10.3390/ijerph15112560.

Czekaj, T., Ciszewski, M., \& Szewczyk, E. M. (2015). Staphylococcus haemolyticus-An emerging threat in the twilight of the antibiotics age. Microbiology, 126, 2061-2068. https://doi.org/10.1099/mic.0.000178.

D’Amato, M., Molino, A., Calabrese, G., et al. (2018). The impact of cold on the respiratory tract and its consequences to respiratory health. Clinical and Translational Allergy, 8, 20. https://doi.org/10.1186/s13601-018-0208-9.

Dehghani, M., Sorooshian, A., Nazmara, S., et al. (2018). Concentration and type of bioaerosols before and after conventional disinfection and sterilization procedures inside hospital operating Rosom. Ecotoxicology and Environmental Safety, 164, 277-282. https://doi.org/10. 1016/j.ecoenv.2018.08.034.

EUCAST-European Committee on Antimicrobial Susceptibility Testing. (2018). Breakpoint tables for interpretation of MICs and zone diameters. Version 8.1 2018. Retrieved May 15, 2018 from http://www.eucast.org.

Fang, Z., Guo, W., Zhang, J., \& Lou, X. (2018). Influence of heat events on the composition of airborne bacterial communities in urban ecosystems. International Journal of Environmental Research and Public Health, 15(10), 2295. https://doi.org/10.3390/ijerph15102295.

Fassatiová, O. (1983). Grzyby mikroskopowe w mikrobiologii technicznej. Warszawa: Wydawnictwo NaukowoTechniczne.

Feller, W. (1950). An introduction to the probability theory and its application. New York: Wiley.

Frías-De León, M. G., Duarte-Escalante, E., del Carmen Calderón-Ezquerro, M., et al. (2015). Diversity and characterization of airborne bacteria at two health institutions. Aerobiologia, 32, 187-198. https://doi.org/10.1007/ s10453-015-9389-z. 
Gola, M., Settimo, G., \& Capolongo, S. (2019). Indoor air quality in inpatient environments: A systematic review on factors that influence chemical pollution in inpatient wards. Journal of Healthcare Engineering, 2019, 8358306. https://doi.org/10.1155/2019/8358306.

Horumpende, P. G., Sonda, T. B., Zwetselaar, M., et al. (2018). Prescription and non-prescription antibiotic dispensing practices in part I and part II pharmacies in Moshi Municipality, Kilimanjaro Region in Tanzania: A simulated clients approach. PLOS ONE, 13(11), e0207465. https://doi.org/10.1371/journal.pone.0207465.

Karimpour, R. S., Godini, H., Nikmanesh, B., et al. (2019). Study on the relationship between the concentration and type of fungal bio-aerosols at indoor and outdoor air in the Children's Medical Center, Tehran, Iran. Environmental Monitoring and Assessment, 191(2), 48. https://doi.org/10. 1007/s10661-018-7183-4.

Karwowska, E., Miaśkiewicz-Pęska, E., \& AndrzejewskaMorzuch, D. (2013). Microbiological air contamination in premises of the primary health-care. Archives of Environmental Protection, 39(4), 51-58. https://doi.org/10.2478/ aep-2013-0034.

Kępa, M., Idzik, D., Wojtyczka, R., \& Pacha, J. (2008). Ocena czystości mikrobiologicznej środowiska Bloku Operacyjnego Szpitala Miejskiego nr $1 \mathrm{w}$ Sosnowcu. Farmaceutyczny Przeglad Naukowy, 4, 33-39.

Khodavaisy, S., Nabili, M., Davari, B., \& Vahedi, M. (2011). Evaluation of bacterial and fungal contamination in the health care workers' hands and rings in the intensive care unit. Journal of Preventive Medicine and Hygiene, 52, 215-218.

Kobza, J., Pastuszka, J. S., \& Brągoszewska, E. (2018). Do exposures to aerosols pose a risk to dental professionals? Occupational Medicine, 68(7), 454-458. https://doi.org/ 10.1093/occmed/kqy095.

Krajewska-Kułak, E., Gniadek, A., \& Kantor, A. (2010). The mycological analysis of air in selected public rooms. Preliminary study. Mikologia Lekarska, 17, 21-29.

Kubera, Ł., Studzińska, J., Dokładna, W., et al. (2015). Microbiological air quality in some kindergartens and antibiotic resistance of bacteria of the Staphylococcus spp. genus. Medycyna Pracy, 66(1), 49-56. https://doi.org/10.13075/ mp.5893.00162.

Labi, A. K., Obeng-Nkrumah, N., Bjerrum, S., et al. (2018). Physicians' knowledge, attitudes, and perceptions concerning antibiotic resistance: a survey in a Ghanaian tertiary care hospital. BMC Health Services Research, 18, 126. https://doi.org/10.1186/s12913-018-2899-y.

Lenart-Boroń, A., Wolny-Koładka, K., \& Juraszek, K. (2017). Phenotypic and molecular assessment of antimicrobial resistance profile of airborne Staphylococcus spp. isolated from flats in Kraków. Aerobiologia, 33(3), 435-444. https://doi.org/10.1007/s10453-017-9481-7.

Lis, D., Pacha, J., \& Idzik, D. (2009). Methicillin resistance of airborne coagulase-negative staphylococci in homes of persons having contact with a hospital environment. American Journal of Infection Control, 37(3), 177-182. https://doi.org/10.1016/j.ajic.2008.09.013.

Lowy, F. D. (2003). Antimicrobial resistance: The example of Staphylococcus aureus. The Journal of Clinical
Investigation, 111(9), 1265-1273. https://doi.org/10.1172/ JCI18535.

Małecka-Adamowicz, M., Kubera, Ł., Jankowiak, E., \& Dembowska, E. (2019). Microbial diversity of bioaerosol inside sports facilities and antibiotic resistance of isolated Staphylococcus spp. Aerobiologia, 35, 731. https://doi.org/10. 1007/s10453-019-09613-y.

May, L., Klein, E. Y., \& Rothman, R. E. (2014). Trends in antibiotic resistance in coagulase-negative Staphylococci in the United States, 1999 to 2012. Antimicrobial Agents and Chemotherapy, 58(3), 1404-1409. https://doi.org/10. 1128/AAC.01908-13.

Mensah-Attipoe, J., \& Toyinbo, O. (2019). Fungal growth and aerosolization from various conditions and materials. In: Fungal infection. IntechOpen. https://doi.org/10.5772/ intechopen.81565.

Miletto, M., \& Lindow, S. E. (2015). Relative and contextual contribution of different sources to the composition and abundance of indoor air bacteria in residences. Microbiome, 3, 61. https://doi.org/10.1186/s40168-015-0128-z.

Mitsakakis, K., Kaman, W. E., Elshout, G., et al. (2018). Challenges in identifying antibiotic resistance targets for point-of-care diagnostics in general practice. Future Microbiology, 13(10), 1157-1164. https://doi.org/10.2217/ fmb-2018-0084.

Mousavi, M. S., Hadei, M., Majlesi, M., et al. (2019). Investigating the effect of several factors on concentrations of bioaerosols in a well-ventilated hospital environment. Environmental Monitoring and Assessment, 191, 407. https://doi.org/10.1007/s10661-019-7559-0.

Nahaei, M. R., Shahmohammadi, M. R., Ebrahimi, S., \& Milani, M. (2015). Detection of methicillin-resistant coagulasenegative staphylococci and surveillance of antibacterial resistance in a multi-center study from Iran. Jundishapur Journal of Microbiology, 8(8), e19945. https://doi.org/10. 5812/jjm.19945v2.

Ökten, S., Şen, B., Asan, A., et al. (2014). Airborne microfungi in Oncology Service of Medical School Hospital of Trakya University. Indoor and Built Environment, 24(6), 771-776. https://doi.org/10.1177/1420326X14533712.

Pallabi, P. (2018). Review on common microbiological contamination found in hospital air. J Microbiol Pathol, 2, 103.

Palmer, A. C., Chait, R., \& Kishony, R. (2018). Nonoptimal gene expression creates latent potential for antibiotic resistance. Molecular Biology and Evolution, 35(11), 2669-2684. https://doi.org/10.1093/molbev/msy163.

Park, D.-U., Yeom, J.-K., \& Lee, W. J. (2013). Assessment of the levels of airborne bacteria, gram-negative bacteria, and fungi in hospital lobbies. International Journal of Environmental Research and Public Health, 10(2), 541-555. https://doi.org/10.3390/ijerph10020541.

Peterson, E., \& Kaur, P. (2018). Antibiotic resistance mechanisms in bacteria: Relationships between resistance determinants of antibiotic producers, environmental bacteria, and clinical pathogens. Frontiers in Microbiology, 9, 2928. https://doi.org/10.3389/fmicb.2018.02928.

Pinheiro, L., Brito, C. I., Oliveira, A., et al. (2015). Staphylococcus epidermidis and Staphylococcus haemolyticus: Molecular detection of cytotoxin and enterotoxingenes. Toxins (Basel), 7(9), 3688-3699. https://doi.org/10.3390/ toxins 7093688 . 
Pląskowska, E., Korol, M., \& Ogórek, R. (2011). Fungi found in air-conditioned room. Part I. Mikrobiologia Lekarska, 18(4), 178-186.

Pląskowska, E., Korol, M., \& Ogórek, R. (2012). Fungi found in air-conditioned room. Part II. Mikrobiologia Lekarska, 19(1), 27-36.

Samson, R. A., Hoekstra, E. S., \& Frisvad, J. C. (2004). Introduction to food- and airborne fungi (7th ed.). Utrecht: Centraalbureau voor Schimmelcultures.

Sapkota, B., Gupta, G. K., Shrestha, S. K., et al. (2016). Microbiological burden in air culture at various units of a tertiary care government hospital in Nepal. AMJ, 9(1), 1-7. https://doi.org/10.4066/AMJ.2015.2558.

Shiferaw, T., Gebre-silasse, L., Mulisa, G., et al. (2016). Bacterial indoor-air load and its implications for healthcareacquired infections in a teaching hospital in Ethiopia. International Journal of Infection Control, 12, i1. https://doi. org/10.3396/IJIC.v12i1.004.16.

Stockwell, R. E., Ballard, E. L., O'Rourke, P., et al. (2019). Indoor hospital air and the impact of ventilation on bioaerosols: A systematic review. Journal of Hospital Infection, 103(2), 175-184. https://doi.org/10.1016/j.jhin. 2019.06.016.

Tršan, M., Seme, K., \& Srčič, S. (2019). The environmental monitoring in hospital pharmacy cleanroom and microbiota catalogue preparation. Saudi Pharmaceutical Journal, 27(4), 455-462. https://doi.org/10.1016/j.jsps.2019. 01.007 .

Twaroch, T. E., Curin, M., Valenta, R., \& Swoboda, I. (2015). Mold allergens in respiratory allergy: From structure to therapy. Allergy, Asthma \& Immunology Research, 7(3), 205-220. https://doi.org/10.4168/aair.2015.7.3.205.

Veysi, R., Heibati, B., Jahangiri, M., et al. (2019). Indoor air quality-induced respiratory symptoms of a hospital staff in Iran. Environmental Monitoring and Assessment, 191, 50. https://doi.org/10.1007/s10661-018-7182-5.

Vos, P., Garrity, G., Jones, D., et al. (2009). Bergey's manual of systematic bacteriology (2nd ed., Vol. 3). New York: Springer. 